\title{
Current Policy Issues in Early Foreign Language Learning
}

JANET ENEVER ${ }^{1}$

$\approx$ The development of policy in relation to language learning at the early primary level of schooling has received only limited attention in the literature on policy studies in general, and within the framework of an emerging education policy space across Europe specifically. This paper offers an introductory discussion of the growth of education policy in Europe, identifying the extent to which the histories of national language policies are being re-shaped by the rise of numerical data and comparison within a newly-formed European education space. A summary review of key measures of particular relevance to early language learning illustrates the scale of "soft" policy mechanisms now available as tools in an on-going process of shaping, adapting and refining policy in response to the continuously shifting language priorities that arise particularly during periods of economic instability. This paper draws on key themes from a transnational, longitudinal study of early language learning in Europe to discuss the extent to which implementation in schools has so far been moulded by a plethora of recommendations, reports and indicators formulated in response to the step change in policy development that has occurred since the publication of the Lisbon Strategy (2000).

Keywords: early language learning, language policy, "soft" policy 


\section{Aktualne dileme politik na področju zgodnjega učenja tujih jezikov}

JANET ENEVER

$\propto$ Razvoju politik na področju učenja tujih jezikov na začetku osnovnega šolanja je bilo posvečene malo pozornosti, in sicer v študijah, ki so obravnavale splošne politike, in tudi v tistih, ki so se ukvarjale z nastajajočimi politikami na področju vzgoje in izobraževanja po vsej Evropi. Prispevek predstavlja uvod v diskusijo o naraščanju števila edukacijskih politik v Evropi. Ugotoviti želi, v kolikšni meri vse večji obseg podatkov in primerjav vpliva na preoblikovanje nacionalnih jezikovnih politik v novonastalem evropskem edukacijskem prostoru. V ekonomski nestabilnosti se prioritete na področju jezika neprestano spreminjajo. Pregled ključnih kazalnikov, še posebej pomembnih za zgodnje poučevanje jezikov, nam pokaže vrsto »mehkih « zakonodajnih mehanizmov, ki so med spreminjanjem postali orodje za oblikovanje, prilagajanje in za izpopolnjevanje politik. V prispevku so predstavljene temeljne točke mednarodne, longitudinalne raziskave zgodnjega učenja jezikov v Evropi, ki so za avtorico osnova pri ugotavljanju razsežnosti sprememb izvajanja zgodnjega učenja in ki so nastale na podlagi množice priporočil, poročil in kazalnikov kot odziv na postopno spreminjanje razvoja politik, ki se je začelo z objavo Lizbonskih strategij (2000).

Ključne besede: zgodnje poučevanje jezikov, politike na področju jezikov, »mehke« politike 
Responding to the title of this special issue, this paper aims to map the emergence of very early language learning from the start of compulsory schooling, reflecting a major shift in the core curriculum of primary/elementary schooling worldwide during the latter half of the 20 th and the early 21 st centuries. As argued by Johnstone (2009, p. 33), this can be identified as "a truly global phenomenon and as possibly the world's biggest policy development in education". As such, reforms have presented a major challenge to policy makers, regional and school-based implementers throughout the world in recent years, and many questions relating to effective implementation and sustainability remain unanswered for the moment. This paper has three sections: firstly, an introductory discussion of worldwide developments in this area; secondly, a focus on policy initiatives in the unique setting of the European Union; and thirdly, a critical evaluation of empirical evidence on current policy implementation in seven European country contexts, drawing on data from the Early Language Learning in Europe study (ELLiE) (Enever, 2011b).

As suggested by the outline for this paper, language policy in education is taken to include the processes of debate and documentation of an actual policy (both from a bottom-up and top-down perspective), the allocation of appropriate resources and the implementation of the policy at school level. Examples of the process of implementation will be drawn from the ELLiE study for the purposes of this paper.

\section{Introduction}

Whilst the early history of foreign language learning (FLL) in statefunded primary/elementary schools remains largely undocumented, examples across Europe can be traced throughout the $20^{\text {th }}$ century, as exemplified by Mihaljevic Djigunovic (2012) reporting from Vilke (2009) that "beginnings [in Croatia] can be traced back to the first half of the $20^{\text {th }}$ century". Johnstone (2009) proposes that there have essentially been three waves of policy that have contributed to phases of lowering the starting age of early language learning (ELL) globally.

- $\quad$ First wave: 1960s. A number of countries, including the United Kingdom, introduced ELL at primary level.

- Second wave: Mid-1980s or early 1990s in many different countries across the world, including Europe.

- Third wave: From early $21^{\text {st }}$ century. Asian countries such as China, South Korea, Taiwan and India. 
The first wave of developments, which emerged in the 1960s, was brought to a halt by the publication of a UK government-commissioned report (Burstall, Jamieson, Cohen, \& Hargreaves, 1974), which concluded that there was no evidence of an advantage gained by the early introduction of foreign languages in the primary school curriculum. Whilst the research premises of this report were later questioned (Gamble \& Smalley, 1975), the effect was that schools across Europe cancelled or curtailed their primary language programmes for some years in the light of this report. With the major political changes of the late 1980s in Europe and the escalating impact of global forces on economies worldwide, interest in ELL was re-configured and new evidence supporting its potential benefits began to emerge. In Europe, many pilot projects were established, including a national longitudinal ten-year study in Croatia that built on the earlier exploratory work conducted by Vilke (Mihaljevic Djigunovic \& Vilke, 2000). In this new climate, both local and national initiatives for the lowering of the starting age began to influence national policy makers, and a number of countries took the first steps towards establishing a compulsory starting age of nine years, or even younger. With the economic growth of Asian countries, this trend has escalated in the early $2 \mathrm{1}^{\text {st }}$ century as former colonies, such as the Indian sub-continent, together with the increasingly strong economies of China, South Korea, Taiwan and Vietnam, have begun to lower the starting age for the introduction of ELL, both in pilot projects and as national policies.

In many of the above contexts, demand for English has been the driving force. Cha and Ham (2008, p. 315), in their extensive analysis of data relating to the growth of English language teaching in schools since the early $20^{\text {th }}$ century, report that globally English has overtaken the provision of other languages since 1945 (in parallel with the growth of the United States as a global economic power). English was represented in only $32.8 \%$ of primary curricula during 1945-1969; growing to nearly $70 \%$ in primary curricula by 2005 (Cha \& Ham, 2008, p. 317). It should be noted here that the term "primary" is frequently applied rather loosely, covering the age groups of 5 to 11 years in the UK; 6 to 12 years in a number of countries and 6 to 14/15 years in many other countries. In some contexts, this term may be synonymous with the terms "elementary" or "basic" schooling. To provide a more precise documentation of the downward shift in national policy decisions for the 27 member countries of the European Union (EU), Table 1 below summarises the recent position. 
Table 1: Europe: recent changes to national compulsory starting age for second/foreign language learning as at May 2011 (Enever, 2011a)

\begin{tabular}{|l|c|c|c|}
\hline \multirow{2}{*}{} & \multicolumn{3}{|c|}{$\begin{array}{c}\text { Compulsory starting age } \\
\text { (for the 27 current EU member countries) }\end{array}$} \\
\cline { 2 - 4 } & 7 yrs. or below & $8-9$ yrs. & $10-11$ yrs. \\
\hline 1990 & 2 & 1 & 24 \\
\hline 2011 & 13 & 10 & 4 \\
\hline
\end{tabular}

Note also that whilst policies in Europe often specify a range of languages that may be introduced, English is overwhelmingly selected as the first foreign language to be learnt. The following section explores the growth of primary school language policies in Europe, within the wider context of the increasing significance of education policy as a key mechanism of governance at a transnational level.

\section{EU language policies in education}

Researchers including Alexiadou and Lange (2013), Lange and Alexiadou (2007, 2010), Lawn and Grek (2012), Pépin (2006) and Rindler Schjerve and Vetter (2012) have charted the growth of education policy in Europe since the 1970s, recording the emergence of mechanisms that have enabled it to operate as a "soft" tool of governance through an emphasis on the production of data, standards and indicators as levers for exerting comparison, competition and a degree of convergence.

Pépin (2006, p. 69) reports that during the 1970s only loose cooperation agreements existed in the field of education, focusing mainly on "mobility, language learning, cooperation in higher education and a European dimension to education". Lawn and Grek (2012, p. 44) emphasise the importance of the shift made by the Treaty on the European Union (1992) (known as the Maastricht Treaty) which "declared that there would be no harmonization of education systems", yet emphasised the economic and policy significance of activities "such as language learning, youth exchanges, collaboration amongst educational institutions and especially student and teacher mobility". From this period onwards, an increasingly European education policy space emerged, which operated "through building relations between people - groups/nations in networks/communities" (ibid., p. 76). A further marker of strategy change was brought in by the Lisbon Strategy (2000) whereby education, now termed "lifelong learning", became a key strand of the new knowledge-based economy goals for Europe. (Jessop, 2008, p. 5). Since that time, recommendations, opinions, reports, joint communications of the Commission and the Education Council, and action plans have operated as persuasive "soft 
law" (Lange \& Alexiadou, 2007, p. 3), whilst data collection has rapidly increased to provide benchmarks and indicators for measuring those aspects of education that can (to some extent) be measured. Lange and Alexiadou (2010, p. 443) also draw attention to the Open Method of Coordination (OMC) which established a procedure for transfers of policy between member states as a result of identified "best practices". This now operates as a key governance strategy for the implementation of the Education and Training Work Programme 2010-2020.

The OMC has been of particular relevance to the languages field in education policy since the Lisbon Strategy (2000), marking a period of profound change in the development of education policy during which the "activity in relation to education is qualitatively different to the pre-20oo era" (Alexiadou \& Lange, 2013). This change is strongly evident in those areas of education policy related to languages. Below, a number of the main "soft" and "hard" devices that have emerged since the year 2000 in the languages area are summarised, revealing the extent to which the OMC has facilitated their rapid growth in support of the European policy for the promotion of multilingualism throughout the EU (Rindler Schjerve \& Vetter, 2012, p. 6).

1994: European Centre for Modern Languages established by the Council of Europe (CoE) in Graz, Austria, functioning as a catalyst for reform in the teaching and learning of languages. Since 2000 , the four yearly programme of activities has increasingly contributed to implementation of $\mathrm{CoE}$ recommendations in national systems.

2000: European Language Portfolio introduced. A mechanism designed for learners of all age groups to record their experiences and progress in language learning. Intended to operate as a CV for labour mobility, but has received only limited success in being embedding within national education systems.

2001: Common European Framework of Reference for Languages (initially formulated in 1996). The European Union Council Resolution recommended using the CEFR to set up systems of validation of language ability; it is now widely used as a set of descriptors for levels of language achievement across all education sectors in Europe and increasingly worldwide.

2004-2006: European Commission Action Plan Promoting Language Learning and Linguistic Diversity 2004-2006 recommended that: "member states should move towards ensuring that foreign language learning at primary school is effective" (Commission of the European Communities, 2003, p. 7). There has been substantial influence on lowering of starting age, but less clear evidence of "effectiveness".

2004: European Profile of Language Teacher Education. Provided a useful reference point, but difficult to assess impact on national systems. 
2005; 2008; 2012: Eurydice key data on languages. Tri-annual summative data on languages provision in Europe published by European Commission - a rich source of comparative data for member states (Eurydice, 2005, 2008, 2012).

2005: Multilingualism institutionalised as a political project with the inclusion of multilingualism in the portfolio of education, training, culture and multilingualism (Rindler Schjerve \& Vetter, 2012, p. 19).

2007: Guide for the Development of Language Education Policies in Europe. Main version (retrieved August, 2, 2012 from www.coe.int/lang). It is difficult to assess the impact of this comprehensive reference document.

2007: European Portfolio for Student Teachers of Languages: no documentation on how widely used currently.

2007: Inter-governmental forum convened by Language Policy Division of $\mathrm{CoE}$ (February 2007) reviewed current and future developments related to the impact of the Common European Framework of Reference for Languages (CEER) with a view to identifying how to extend its impact (Martyniuk, 2007, p. 23).

2007: A discrete multilingualism portfolio for Europe created, appointing the first Commissioner for Multilingualism.

2007-2013: Lifelong Learning Programme (LLP). Allocated funding of $€ 7$ billion over seven years for language projects/research; indicative of rise in prioritising of languages policy.

2007: European Commission (EC) language support in programmes such as Comenius, Erasmus, Leonardo da Vinci, Grundtvig, The European Language Label, eTwinning, ICT, Naric, Days of Languages.

2007: Report of the High Level Group on Multilingualism Council of Europe. Advised on impact of "soft" policy within European and global context.

2008: Report by group of intellectuals (led by Amin Maalouf) advised EU on languages and intercultural issues.

2009: Piccolingo campaign launched by European Commission with aim of raising parents' awareness of the benefits of early language learning and at providing practical information and support (European Commission, 2009).

2010: The multilingualism portfolio re-integrated within the portfolio of the commissioner for education, culture, multilingualism and youth.

2010: Provisions of the Lisbon Treaty (2000) regarding linguistic diversity and in respect of linguistic minorities became legally binding (OJ $2010 \mathrm{C} 83$ Charter: See Articles 21, 22 and 41).

2011: Follow-up initiative from Piccolingo launch: publication of the handbook Language learning at the pre-primary school level (European Commission, 2011). 2012: SurveyLang. European Survey on Language Competencies (European Commission). Data comparing language achievements of 15-year olds in 16 
participating European countries. It is anticipated this will increase future likelihood of comparison and convergence in national policies.

The wide range of "soft" policy measures summarised above include a number of tools to provide statistical data, indicators and measurement instruments applicable across differing education systems, together with mechanisms that aim to support the effective implementation of policy recommendations. Many funded research studies and language projects have facilitated extensive networking opportunities bringing together a diverse mix of language professionals to review and interpret the relevance of indicators to their specific language contexts, thus increasing the likelihood of effective implementation. The substantial financial investment involved in these initiatives is regularly evaluated in response to political calls for achieving cost-effective returns. However, given the multiple agencies involved in the above measures, each bringing their unique agendas to the table, attempts to evaluate effectiveness are inevitably confronted with multi-level, complex variables to isolate or to combine and digest, sometimes producing an over-simplified, "sound-bite" analysis or alternatively an analysis of such multi-dimensionality that only limited conclusions are possible. Nonetheless, a principal advantage of this networking approach to policy formation is that it allows policy formation to be on-going, fluid and performance driven. This flexibility is in marked contrast with previous systems which tended to "fix" policy for set periods of (for example) ten years before the documentation was updated and re-drafted. Given the impact of global forces on language choice and language use across all domains of life today, flexible policy frameworks seem more likely to facilitate speedier local and national responses to changing needs for languages under conditions of uncertainty and instability in Europe and beyond. As one example of how funded research is able to contribute to the on-going evidence base of language policy implementation, the next section will discuss key policy findings from the ELLiE study on the introduction of language learning from the very start of compulsory schooling in Europe.

\section{Policy findings from the ELLiE study}

The ELLiE study (2006-10) was established by a team of expert researchers based in seven European countries (Croatia, England, Italy, Netherlands, Poland, Spain and Sweden). Following an initial scoping year (2006-7), partly funded by the British Council, the team were awarded research funding for a larger study by the European Commission (Lifelong Learning Programme 2007-13) which placed specific requirements on the team to develop indicators "addressing weaknesses in 
preschools and in obligatory education concerning acquisition of key competences" (European Commission, 2006, p. 19). This transversal programme embodied an expectation that the research should contribute to the implementation of the Lisbon process by helping to shape future policies at both national and European levels. In response to this priority, the research team took the view that the study should aim to collect data that could clearly reflect the realities of policy implementation across a range of school contexts, revealing the challenges encountered and identifying evidence for the first steps of achievement made towards acquiring the key competency of a foreign language, in the broadest sense possible. The transnational setting of seven country contexts allowed the team to develop a research framework comprising a convenience sample of schools, with a geographical spread and socio-economic range in each context, offering the potential for a broad perspective on early language learning in Europe through the comprehensive data collection and processing procedures made possible by a longitudinal study (2006-10). Data was collected from over 1400 children, their parents, teachers and school principals over the four year period. Figure 1 summarises each of the policy areas relevant to early language learning in Europe for which data was collected in the ELLiE study. The following section will focus on those aspects of policy implementation that have received most emphasis in the "soft" policy recommendations of the various OMC initiatives referred to above. These include those strands most closely related to teacher preparation and to the learner's context for learning.

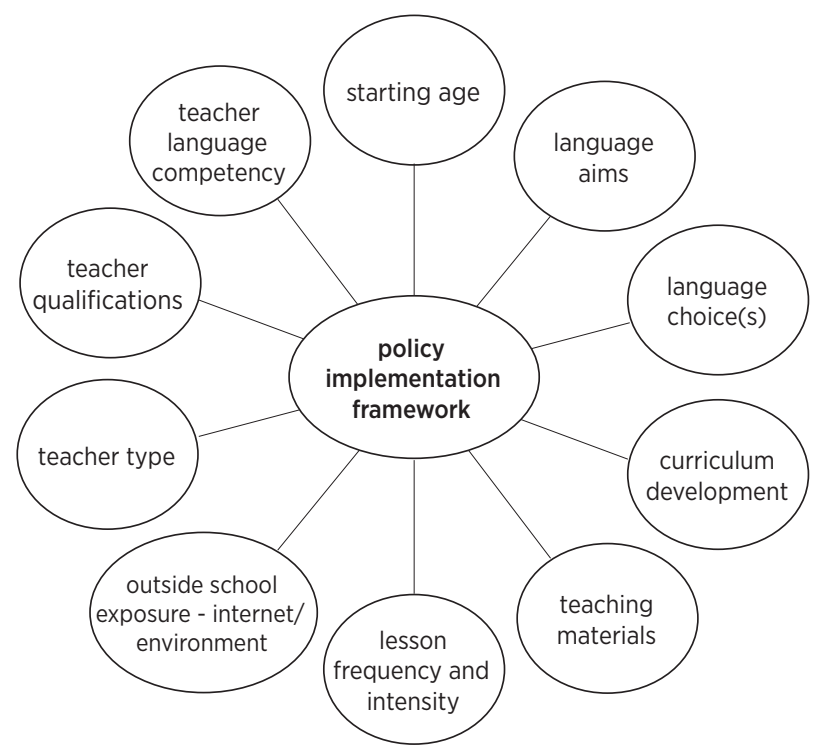

Figure 1: ELLiE policy planning model (Enever, 2011, p. 40) 


\section{The learner's context for learning}

\section{Starting age}

European Commission documents and reports since the publication of the Action Plan (2004-06) have consistently emphasised the importance of foreign language introduction at the early primary or pre-primary phase of education. More precise guidance on the optimal starting age is unclear, although a recent report on language learning in the pre-school years (European Commission, 2011) argues for the benefits of an earlier start in non-formal settings. The report notes however that such initiatives are somewhat ad hoc at present, but it appears to perceive these developments positively, anticipating growth in this area across Europe. In addition, there are a number of studies that have explored the question of an early start to language learning in school contexts. These include: Munoz, 2006; Nikolov and Mihaljevic Djigunovic, 2006; Apeltauer and Hoppenstedt, 2010. A further extensive review of published research by Edelenbos, Johnstone and Kubanek (2006) found that early language learners tended to be more successful, but that research evidence accounting for this success was inconclusive. The researchers offered the explanation that:

" $[S]$ tarting earlier may lead to an increase in time and intensity of experience and through that to better performances in the foreign language at the end of formal education" (Edelenbos, Johnstone, \& Kubanek, 2006, p. 147).

Against this background, the ELLiE study found evidence of an increasingly earlier start across all seven country contexts, with Italy, Spain, Croatia and Poland opting for a compulsory starting age of six or seven years, England promoting the concept of "an entitlement" to foreign language learning from age seven (stopping short of a mandatory starting age, given the current political and financial ramifications), whilst the Netherlands and Sweden retained a compulsory starting age of ten years, but allowing schools to decide to start earlier. Increasingly, schools in both countries have introduced the first foreign language in year one or two. Given the lack of conclusive empirical evidence on an optimal starting age, the policy responses of these countries may well have been influenced by a number of the "soft" policy measures listed above, together with the mounting pressure to conform that may be experienced as a result of comparative data now widely available.

\section{Language choice and aims}

Multilingualism has been viewed as a high priority since the 1990 s 
in Europe. Rindler, Schjerve and Vetter (2012, p. 17) report that: "In the past few years [...] the multilingualism project has substantially widened its thematic scope". As evidence for this they cite an EC report on multilingualism (COM, 2008, 566 final) that "underlines that multilingualism should be "mainstreamed" across a series of EU policy areas, including lifelong learning, employment, social inclusion, competitiveness, culture, youth and civil society, research, translation and the media". The extent to which this policy perspective is reflected in the countries of the ELLiE study varies. Poland and Croatia list a few language options in their primary policy documents, Spain, the Netherlands and England devolve choices to local authorities or schools, whilst Italy and Sweden specify English as the first language to be introduced. Notably, Sweden refers to English as a core subject (rather than a foreign language), with foreign languages to be introduced later. Despite the degree of freedom evident in some policy documents, all schools involved in the ELLiE research had selected English as the first foreign language to be introduced (except England, where French was most commonly found). Here it seems that "soft" policy has had little impact, and that contemporary perceptions of English as a globally dominant language may well have influenced policy makers.

Related to this, Rindler, Schjerve and Vetter (2012, p. 30), interestingly, note that the European survey on language competencies (European Commission, 2012) provided data on test results related only to the five most widely taught languages in Europe. Here, they suggest "It could be argued that the European language education policy is a failure [...] since the FLs [foreign languages] actually selected by Europeans are very limited" (ibid., p. 30).

Policy documentation related to language aims appears to be considerably more influenced by the OMC, with the possible exception of Croatia. All seven countries anticipate an achievement level of at least A1, with some expecting to approach an A2 level by the end of primary. Notably, all seven countries have incorporated CEFR level descriptors in documentation despite its limited relevance to this age group. Croatia's distinctive emphasis on the importance of a multisensory and holistic approach in the first four years of ELL (ages 6-10 years) undoubtedly owes much to the country's long experience and substantial empirical evidence in this field (Mihaljevic Djigunovic \& Vilke, 2000), whilst the lack of convergence with the other ELLiE contexts may well reflect its current position as an applicant country to the EU, thus experiencing less exposure to the full impact of OMC measures. 


\section{Teacher preparation}

\section{Teacher qualifications}

In the area of teacher preparation at both pre and in-service levels, there seems to be the greatest variation in provision and funding availability across the countries of the ELLiE study. Lesson observation indicated that provision was extremely inadequate in some cases, often leaving teachers to cope in classrooms where they were ill-prepared for the challenges of engaging young children in a mainly oral foreign language learning experience for periods of 30-45 minutes. Some aspects of this limited teacher preparation can be attributed to the relatively recent policy introduction. Poland and England for example have begun to introduce early primary foreign languages only since 2005, whilst the Netherlands and Sweden currently do not have a compulsory policy for the age group of 6-10 years. Spain, Croatia and Italy, however, have had a series of initiatives over the past twenty years that could well have resulted in a comprehensive teacher preparation programme at both pre- and in-service levels by 2012, yet still appears to have a number of weaknesses in the current programme.

Part of the reason for somewhat limited provision may be explained by particular histories of teacher foreign language preparation in some countries. Eurydice (2008) identified three main categories of foreign language teachers to be found in Europe (across primary and secondary phases of education). Figure 2 summarises these, together with the addition of a further category of "unqualified teacher" that was evident in some classrooms of the ELLiE study.

\section{Teacher Qualifications}

General teacher A teacher qualified to teach all (or almost all) subjects in the curriculum, including the foreign language, irrespective of whether they have received specific training in this field.

Specialist teacher A teacher qualified either to teach two different subjects, one of which is a foreign language, or qualified solely to teach foreign languages.

Semi-specialist teacher A teacher qualified to teach a group of at least three different subjects, one or more of which is foreign languages.

Unqualified teacher Not defined by Eurydice. Examples include: in England there are higher teaching assistants teaching the foreign language, generally native speakers or holding university degrees in the target language.

Figure 2: European FL teacher qualification categories (adapted from Eurydice, 2008, p. 77) (Enever, 2011b, p. 26).

All four categories of FL teacher were found in ELLiE schools, with some tendency towards a specialist or semi-specialist being more common. Where this applied, the teacher would be more likely to teach across all age ranges, 
from six to sixteen years in some cases. Given the demanding preparation necessary for meeting the needs of older learners, inevitably teacher preparation for this profile is less likely to include an emphasis on the story, rhyme and game-type activities so necessary for the engaging young children in the challenging task of understanding that meanings can be made by producing quite unfamiliar series of sounds. This approach to the planning of teacher provision is now much in need of revision.

The provision of relevant pre-service courses in Italy, England and the Netherlands was found to be insufficient to supply well-trained professionals for all schools. Pre-service provision in Poland was generally adequate, but there was strong evidence that qualified teachers often took better-paid jobs in offices, private schools or travelled abroad to market their language skills. Spain and Croatia generally had adequate provision, whilst Sweden introduced a compulsory strand of ELL to all primary pre-service courses in 2011.

The provision of in-service arguably is a more pressing priority for policy makers. In those countries where teachers are appointed as civil servants, there often exists a perception of a "job for life". Consequently, teachers holding these positions are unlikely to leave their posts, and thus will be in need of training, both in age-appropriate methodology and language competency. Short courses or regular workshops have been provided in most countries, but these may be optional and less well attended. In Poland, Spain and Sweden, provision is too limited, whereas in England and the Netherlands it is adequate, but optional, at least within the regional contexts where the ELLiE data was collected. Italy generally seemed to achieve good attendance and made good provision, as did Croatia.

Overall, it can be said that much still remains to be done in terms of achieving adequate quality of course provision and national coverage in a number of the ELLiE countries. Here, the instruments of "soft" policy, such as the European profile of language teacher education (2004), the European portfolio for student teachers of languages, and the activities of ECML, appear not to have yet achieved a substantial impact on pre and in-service provision.

\section{Teacher language competency}

Linked to the question of quality teacher preparation are concerns of language competency for teachers of ELL. Lesson observation throughout the four years of the ELLiE study confirmed the research team's view that a high level of fluency is particularly necessary for teaching this age group. A final recommendation of the ELLiE team was that a $\mathrm{C}_{1}$ level should be the language target for all teachers, with a lower entry point of B1-B2. Language qualifications varied amongst the ELLiE countries. Both England and Sweden had no 
measure of language competency. Italy set an exam at B1 level. Spain, Italy and Croatia include a language exam as a part of their teacher qualification programme, whilst Poland and the Netherlands require a B2 level certification.

Amongst the ELLiE schools observed, almost all teachers had achieved at least a B1 level, with some well in excess of this. However, it was evident that this level of fluency was not always combined with a skill in taking a flexible approach to language use, varying the choice of $\mathrm{L}_{1} / \mathrm{L}_{2}$ and selecting language focuses that would engage young children sufficiently. This finding reflects the need for both improved language competency and teacher preparation that includes a focus on teacher language choices in early start classrooms.

Whilst it is evident that the OMC has resulted in the development of a number of useful guidance documents and other initiatives for language teacher preparation, it appears that these have had only limited results for quality provision so far. Much of the reluctance to ensuring sufficient provision may relate to the substantial costs involved and to the relatively longer-term planning that is necessary for an investment in quality. However, there are sufficient models of good provision now available in Europe for policy makers to start to invest in a supply of well-prepared teachers for the next generation of young language learners. It seems that here the OMC mechanism could usefully contribute to stimulating actions to ensure a much more satisfactory spread of preand in-service programmes for teachers in the near future.

This section on policy findings has aimed to review the extent to which the OMC has provided effective tools for the shaping and refining of policy implementation in ELL. It seems that some measures have proved particularly useful whilst others have merely served to provide conformity - possibly for little reason. On the question of quality teacher provision, it may well be that this is a much longer-term challenge that will simply take time to effectively implement. It may also be the case that the politics of commitment to funding have limited progress. To some extent though, this area of policy initiative may suffer from the perennial problems of the low status of primary teachers in general. Typically, primary teachers receive lower pay than their secondary school colleagues. Historically, primary teacher preparation was conducted outside the university environment and often viewed as more of a vocational post than the positions of subject teachers at secondary school level, and thus had lower status. Today across Europe, primary teacher education (including primary language teachers) are generally required to achieve a university degree and possibly an additional postgraduate qualification, however, the stigma of "lower status" still seems somehow to be attached to this. It appears that the professionalisation of the field of ELL remains still to be fully realised. 


\section{Conclusion}

This paper has set out some of the contemporary challenges confronted by policy makers in formulating frameworks to effectively implement ELL in Europe. The particular sociocultural histories of individual nation states add to the multi-layered complexity of designing policies to meet the unknown future needs of this generation of young Europeans. The current economic climate in Europe places further extreme limitations on what can be achieved. Tendencies towards increased labour mobility in recent years, resulting in more families moving across the language borders of Europe, has rapidly escalated the need for better provision of ELL in all European contexts. In these unstable times, it seems likely that there will be yet more challenges ahead for schools, teachers and policy makers to overcome.

Within such a climate, the flexibility of the OMC appears to offer a better mechanism for the on-going shaping and refining of policy than previous approaches to policy formation, which were often ill-equipped to respond quickly to changed circumstances. A note of caution should be exercised here however. The trend towards a heavy reliance on measureable data risks the undervaluing of those features that do not lend themselves to measurement. Subsequent comparisons across countries create a multiplier effect, whereby many qualitative features of good provision and practice are ignored completely. To some extent, the ELLiE study attempted to avoid this pitfall by combining detailed qualitative evidence with quantitative data to construct an analysis more closely related to the complexity of real classroom environments. More research along these lines is needed if we are to fully understand how to shape policies for the future.

\section{References}

Alexiadou, N., \& Lange, B. (2013; accepted for publication ). Deflecting European Union influence on national education policy-making: the case of the United Kingdom. Journal of European Integration. Apeltauer, E., \& Hoppenstedt, G. (2010). Meine Sprache als Chance - Handbuch zur Förderung der Mehrsprachigkeit. Troisdorf, Germany: Bildungsverlag Eins.

Burstall, C., Jamieson, M., Cohen, S., \& Hargreaves, M. (1974). Primary French in the Balance. Slough, UK: NFER Publishing Co.

Cha, Y. K., \& Ham, S. H. (2008). The impact of English on the school curriculum. In B. Spolsky \& F. Hult (Eds.), The handbook of educational linguistics (pp. 313-328). London: Blackwell.

Commission of the European Communities (2003). Communication from the Commission to the Council, the European Parliament, the European Economic and Social Committee and the Committee of the Regions: Promoting Language Learning and Linguistic diversity: An Action Plan 
2004-2006. COM (2003) 449 final. Retreived 2.8. 2012 from http://ec.europa.eu/education/doc/ official/keydoc/actlang/act_lang_en.pdf

Commission of the European Communities (2007). Report of the High Level Group on

Multilingualism Council of Europe. Luxembourg: Office for Official Publications of the European

Communities.

Commission of the European Communities (2008). Communication from the Commission to the European Parliament, the Council, the European Economic and Social Committee and the Committee of the Regions. An updated strategic framework for European cooperation in education and training.COM (2008) 566 final. Retreived from http://ec.europa.eu/education/lifelong-learningpolicy/doc/com865_en.pdf Council of Europe (2001). Common European Framework of Reference for Languages: Learning, teaching, assessment. Cambridge: Cambridge University Press.

Council of Europe (2007). Guide for the development of language education policies in Europe.

Strasbourg: CoE. Language Policy Division.

Edelenbos, P., Johnstone, R., \& Kubanek, A. (2006). The main pedagogical principles underlying the teaching of languages to very young learners, languages for the children of Europe, Published Research, Good practice \& main principles. London: European Commission.

Enever, J. (2011a). Plurilingualism? Have language-in-education policies in Europe delivered the promise? [Plurilingüismo? Han cumplido lo prometido las politicas europeas de education lingüistica?] In P. Powell-Davies (Ed.), Word for Word. The social, economic and political impact of Spanish and English [Palabra por palabra. El impact social, economic y politico del español y del inglés]. España: Instituto Cervantes/British Council.

Enever, J. (Ed.) (2011b). ELLiE. Early Language Learning in Europe. London UK: British Council. Retreived 10.5.2012 from http://www.teachingenglish.org.uk/publications/early-language-learningeurope

Enever, J., Moon, J., \& Raman, U. (Eds.) (2009). Young Learner English Language Policy and Implementation: international Perspectives. UK: Garnet Education.

European Commission (2006). Lifelong Learning Programme: Part I - Priorities of the 2007 general call for proposals. Key Activityi: Policy Cooperation and Innovation. Brussels: Commission of the European Communities.

European Commission (2011). Policy Handbook. Language learning at pre-primary school: making it efficient and sustainable. Retreived 2.8.2012 from http://ec.europa.eu/languages/orphans/ background-documents_en.htm European Commission (2009). Piccolingo campaign on early language learning. Retreived 2.8.2012 from http://ec.europa.eu/languages/news/20091002-kick-off-of-the-piccolingo-campaign-on-earlylanguage-learning_en.htm

European Commission (2012). SurveyLang. European Survey on Language Competencies. Brussels: European Commission.

Eurydice Network (2005, 2008, 2012). Eurydice: Key data on teaching languages at schools in Europe. 
Brussels: Commission of the European Communities. Retrieved 30.10.2012 from http://eacea. ec.europa.eu/education/eurydice/key_data_en.php

Gamble, C., \& Smalley, A. (1975). Primary French in the balance - 'Were the scales accurate?' Journal of Modern Languages, 94(7), 4-97.

Jessop, B. (2008). The Knowledge-based economy. Naked Punch, 10, 2. Retreived 2.8.2012 from http:// eprints.lancs.ac.uk/1007/

Johnstone, R. (2009) An early start: What are the key conditions for generalized success? In J.

Enever, J. Moon \& U. Raman (Eds.), Young Learner English Language Policy and Implementation:

International Perspectives (pp. 31-42). Reading, UK: Garnet Education

Lange, B., \& Alexiadou, N. (2007). New forms of European Union governance in the education sector? A preliminary analysis of the Open Method of Coordination. European Educational Research Journal, 6(4), 321-335.

Lange, B., \& Alexiadou, N. (2010). Policy learning and governance of education policy in the EU. Journal of Education Policy, 25(4), 443-463.

Lawn, M., \& Grek, S. (2012). Europeanizing Education. Oxford, UK: Symposium Books. Lo Bianco, J. (2009). 'Second languages and Australian schooling'. Melbourne: ACER. Australian education review, 54 .

Malouf, A. (2008). Report from the Group of Intellectuals for Intercultural Dialogue. Brussels: European Commission. Retreived 2.8.2012 from http://ec.europa.eu/education/policies/lang/doc/ maalouf/report_en.pdf

Martyniuk, W. (2007). Forum for Progress. EL Gazette, (328), 23.

Mihaljevic Djigunovic, J. (2012). Early EFL learning in context - Evidence from a country case study. ELT Research Papers 12-05. London, UK: British Council. Retrieved 30.10.2012 from http://www. teachingenglish.org.uk/sites/teacheng/files/B376\%20ELTRP\%2oReport\%20-\%20ELLiE\%20v8.pdf Mihaljevic Djigunovic, J., \& Vilke, M. (2000). Eight Years After: Wishful Thinking vs Facts of Life. In J. Moon \& M. Nikolov (Eds.), Research into Teaching English to Young Learners (pp. 66-86). Pecs, Hungary: University Press, Pecs.

Munoz, C. (Ed.) (2006). Age and the rate of Foreign Language Learning. Clevedon, UK: Multilingual Matters.

Nikolov, M., \& Mihaljevic Djigunovic, J. (2006). 'Recent research on age, second language acquisition, and early foreign language learning. Annual Review of Applied Linguistics, 26, 234- 260.

OJ 2010 C 83 Charter: Charter of Fundamental Rights of the European Union. 30.03.10, 389-403.

Retreived 2.8.2012 from http://eur-lex.europa.eu/LexUriServ/LexUriServ.do?uri=OJ:C:2010:083:0389 :0403:EN:PDF

Pépin, I. (2006). The history of European cooperation in education and training: Europe in the making - an example. Luxembourg: Office for official publications of the European Communities. Rindler Schjerve, R., \& Vetter, E. (2012). European Multilingualism. Current perspectives and challenges. Bristol, UK: Multilingual Matters.

Vilke, M. (2007). English in Croatia - A glimpse into past, present and future. Metodika, 8(14), 17-24. 


\section{Biographical note}

JANET ENEVER, Professor, from Umeå University, Sweden, teaches in the broad field of foreign language education and researches on language policy, early language learning and language and globalisation. She has taught at universities in London, Hungary and Poland and advised on language policy, early language learning and teacher education for ministries in a number of Asian and European countries. Her recent publications include a study of early language learning in Europe (ELLiE) and an edited book on primary language policies around the world (co-edited with Jayne Moon). 